Newfoundland and Labrador Studies

\title{
Ursula A. Kelly and Meghan C. Forsyth. The Music of Our Burnished Axes: Songs and Stories of the Woods Workers of Newfoundland and Labrador
}

\section{Lachlan MacKinnon}

Volume 34, Number 1, 2019

URI: https://id.erudit.org/iderudit/1072442ar

DOI: https://doi.org/10.7202/1072442ar

See table of contents

Publisher(s)

Faculty of Arts, Memorial University

ISSN

1719-1726 (print)

1715-1430 (digital)

Explore this journal

\section{Cite this review}

MacKinnon, L. (2019). Review of [Ursula A. Kelly and Meghan C. Forsyth. The Music of Our Burnished Axes: Songs and Stories of the Woods Workers of Newfoundland and Labrador]. Newfoundland and Labrador Studies, 34(1), 174-177. https://doi.org/10.7202/1072442ar 
Ursula A. Kelly and Meghan C. Forsyth. The Music of Our Burnished Axes: Songs and Stories of the Woods Workers of Nerwfoundland and Labrador. St. John's: ISER Books, 2018. ISBN 978-1-894725-40-8

The Music of Our Burnished Axes is a timely unpacking of occupational culture from the woods of Newfoundland and Labrador. Oral tradition looms large; indeed, the majority of the book is dedicated to anthologizing and annotating 76 songs and tunes, 14 recitations, 23 poems, and 11 narratives and first-person accounts that the authors have painstakingly collected and historically situated. In three contextualizing chapters, the history and culture of lumbering and logging in Newfoundland and Labrador are brought into focus. Ursula Kelly's chapters trace the functional aspects of oral tradition in the woods, noting how "songs and stories showed [the creators'] critical insight and wit, as well as an appreciation of their own labour and value" (43). The reader is left with a keen sense of how each song or story is produced from within a vibrant social and occupational fabric that encompasses disparate themes of gender, political economy, labour, and settler-Indigenous relationships. Meghan Forsyth's ethnomusicological training is readily visible in her chapter (57), which interrogates not only the lyrical content of these songs and stories, but areas of shared structure, musical intent, and transcription choices.

The authors' treatment of gender within these forms of cultural production is particularly praiseworthy. Indeed, the songs and stories of woods workers provide a hitherto unexamined source for understanding working-class conceptions of work, family, masculinity, and femininity in Newfoundland and Labrador. Through the production of songs and stories, such conceptions are literally and symbolically performed. The authors deftly reveal the contours of gendered meanings for men in the woods, both through a close reading of the songs and stories and through the consideration of what stories are not told. As Kelly reminds us, songs that are humorous or lewd have long been used to solidify collective notions about the masculinity or hard-man character of work in the woods, but the relative absence of more emotive 
songs detailing notions of familial separation, for example, might also indicate a broader uncomfortableness with such themes within maleoriented cultures (46). This point is underscored by the relative absence of women from lumbering songs; indeed, "Slaughter Cove Pond" (122) - the only song in this collection authored by a woman - mentions the presence of women and children within the camps.

Indigenous people were integral to the operations of the lumber camps and mill towns. Drawing on an extensive array of historical literature, Kelly describes the participation of the Innu, Inuit, and Mi'kmaq in the burgeoning forestry economy (20-21). In the songs and stories, though, the interplay between Indigenous and settler peoples is less visible. "Labrador Peace" is the one song in which the dimensions of these interactions are explicitly discussed (243) - and there, only in terms of the displacement of Indigenous people by the modernizing forces of industry. This is contrasted with the account of John Nick Jeddore, a Mi'kmaw forester who served in Scotland under the Newfoundland Overseas Forestry Unit during the Second World War. In Jeddore's story, his Indigeneity informed his position ("Being an Indian and a hunter, I was a natural for this") and did not conflict significantly with either his experience in industrial forestry or his social life in the United Kingdom (410). While understandably constrained by the types of available sources, the authors might well have probed more deeply into the confluence of Indigeneity, identity, industry, and colonialism that has begun to inform other recent work on Canadian forestry (High, 2018).

This collection will be of great interest to Canadian labour historians. The authors distinguish between songs and stories of work, which generally focus on process and experience, and labour songs, which deal explicitly with class politics in the woods and mill towns. In their extensive analysis of these cultural representations, Kelly and Forsyth pay close attention not only to the materials that are available, but also to the stories and perspectives that went unperformed.

The book's treatment of the 1959 International Woodworkers of America (IWA) strike is an insightful example. While the woods 
workers supported the IWA, public opinion in Newfoundland and Labrador slowly turned against the union during the strike — with a significant shift in public opinion occurring in March when a police officer was killed during a confrontation with picketing workers. Joseph Smallwood resolved the conflict by stripping the IWA of its collective bargaining rights and forcing the strikers to accept the authority of the Newfoundland Brotherhood of Wood Workers. While Kelly and Forsyth describe retrieving several songs and stories that detail these events, few of these were created by woods workers or reflect positively about the IWA $(198,202,206)$. Indeed, as they describe, "the dearth of songs that reflect [loggers'] point of view may suggest a prohibition they sensed about pro-IWA sentiment after the strike" (36). Exceptions to this were written decades after the events in question $(230,271)$ and dealt only sparingly with the sense of grievance produced by Smallwood's actions.

In her reflection on song compositions after the 1960s, Ursula Kelly argues that "the extent and kind of song composition changed as the culture of woods work changed and as American popular culture increasingly positioned people as consumers rather than producers of culture" (37). She rightly places this changing culture within a context of falling employment in woods work, but it would have been worthwhile to bring these two shifts - material and cultural - into more direct conversation. I wondered, for example, if the relative decline of woods workers' organizational power during this period was a direct catalyst for the production of songs or stories that framed the IWA strike in more positive terms. In other words, did such representations only arise once it was "safe" to do so, in the sense that woods workers were no longer able to functionally threaten the status quo as they perhaps had in 1959?

The Music of Our Burnished Axes provides a corpus of material that is ripe for future research. It would be fascinating, for instance, to apply a comparative approach in the analysis of woods workers' cultural productions and those produced by workers in other sectors of the deindustrializing economy. Was the desire to "recall a time that had passed 
rather than to record experience as it unfolded" (37) a component part of a broader shift in the Canadian class landscape? Likewise, ethnomusicologists will find the discussion of occupational music-making particularly compelling. Overall, this book represents a multidisciplinary intervention into the understanding of working-class culture in Atlantic Canada. It is commendable both for the breadth of the authors' research and for the success of their efforts to let the sources speak for themselves. Indeed, it is in this final effort that they are perhaps most successful. In the songs, stories, and poems presented in this collection, the voices of woods workers in Newfoundland and Labrador resound with great clarity.

\section{Reference}

High, Steven. One Job Town: Work, Belonging, and Betrayal in Northern Ontario. Toronto: University of Toronto Press, 2018.

Lachlan MacKinnon

Cape Breton University

Rosalind Gill. Too Unspeakable for Words. St. John's: Breakwater Books, 2017. ISBN 978-1-77103-106-6

Rosalind Gill's collection of short stories is a quick read, and it was one that I loved: this slender volume (only 153 pages in length) is full of powerful emotions, memorable characters, and intriguing, if relatively ordinary, scenarios. One may think that the collection's focus on local places and its aestheticization of the familiar, even mundane, parts of everyday life in this province make it generic since these elements appear in many of Newfoundland's cultural products. However, 